\title{
People's Attitudes to Healthy Exercise Diet, a Market Investigation
}

\author{
Kaijun Zhang ${ }^{1, *}$, Wenyao Fan ${ }^{2}$ \\ ${ }^{1}$ Marketing, Nanjing University of Finances and Economics, Nanjing, China \\ ${ }^{2}$ Medical Imaging, Medical College of Shantou University, Shantou, China
}

Email address:

519425207@qq.com (Kaijun Zhang)

\section{To cite this article:}

Kaijun Zhang, Wenyao Fan. People's Attitudes to Healthy Exercise Diet, a Market Investigation. Humanities and Social Sciences. Vol. 3, No. 5, 2015, pp. 276-279. doi: 10.11648/j.hss.20150305.28

\begin{abstract}
To investigate the market conditions of different individuals' demands toward exercise meal, we use the questionnaires, including online questionnaires and real questionnaires .The content consist of respondents' basic informations and their views of exercise diet. In the survey, objects (20-55 years old, average $28 \pm 0.7$ years old) include individuals in public exercise group $(n=520)$ who totally consume $1200-4000$ yuan a month and in high-earning group( $n=97)$ who totally consume more than 4000 yuan a month. The propotion of those who will consume exercise meals is more than 76\%(468/617), among them, three hundred and eighty-six respondents are from public fitness group, occupying 82.4\%(386/468); Eighty-two respondents are in the high-earning group, accounting for $17.6 \%(82 / 468)$. Of the health and fitness-related participants, $69.8 \%(327 / 468)$ of objects are identified as female. The ratio of People who like the health fitness catering service are significant difference between high-earning group and public fitness group $(\mathrm{p}<0.05)$. Public fitness group and high-consume group think highly important of healthy exercise diet. While the high-consume group have a higher demand of private customized health fitness catering service, with there is market gap in this field, a third party which provide healthy diet should be set to reach public healthy demands. When considering about what it should do, we set five more questions to finish the customer psychology research. It is about their thought about the food itself, the source of food, the location of company, the way receiving services and (what) the place company can be. The feedback shows not only the views of healthy diet, but also public customer psychology.
\end{abstract}

Keywords: Healthy Exercise Diet, High-Earning Group, Public-Fitness Group, Marketing Conditions

\section{Introduction}

The number of individuals who join exercise is growing, the exercise time of public group is rising too. Both of these factors have boosted the related industry development, while the fitness industry has shown a vast growth in the past decades. When participating in fitness, there is always a question of "what is the best diet for health fitness?" As well known, body dissatisfaction and dieting behavior are considered risk factors for the development of disordered eating behavior (DE) and eating disorders (ED) [1]. It is an utterly difficult condition for those who have eating disorders. As research show, the psychology that seeking for slim body and beauty and diet is an identified risk factor which have been reliably connected to the development of eating disorders. And being young, female and dieting, which is a huge group ,is easily to have this kind of psychology. At this time, if a third party provides balanced nutrition and healthy exercise diet to keep us energized, meanwhile it do not cause calorie overload and weight gain, who will be interesting in it and who will rely on this way to keep fit? Beyond health, do these people also think highly important on the taste and the source of the food? And if the company which provides such diet will be set up, what are the strengths and weaknesses, opportunities and threats it will be up against? In this study, we will investigate the market conditions of different individuals' demands toward exercise meal.

\section{Materials and Methods}

Using the questionnaires, including online questionnaires and real questionnaires, and designing several research charts after collecting the valid questionnaires. The content consist of respondents' basic information and their views of exercise 
diet. Survey objects (20-55 years old) include individuals in public exercise group $(\mathrm{n}=520)$ who totally consume $1200-4000$ yuan a month and in high-earning group $(n=97)$ who totally consume more than 4000 yuan a month. Chi-square analysis has been used for the differences between groups.

\section{Results}

Feedbacks from 617 questionnaires (female: male $=357$ : 266 ) shows the propotion of those who will consume exercise meals is more than 76\% (468/617), among them, three hundred and eighty-six respondents are from public fitness group, occupying 82.4\% (386/468); Eighty-two respondents are in the high-earning group, accounting for $17.6 \%(82 / 468)$. They will rely on third party to prepare their exercise meals especially when their self condition do not allow them to meet demands of exercise meals, those who have no desire to consume exercise meal accounts for 24\% (149/617) (figure1). The ratio of people who like the health fitness catering service are significant difference between high-earning group and public fitness group $(p<0.05)($ table 1$)$.

Table 1. Table of people who like the health fitness catering service in high-earning group and public fitness group.

\begin{tabular}{clll}
\hline group & like & dislike & total \\
\hline public exercise & 386 & 134 & 520 \\
high-earning & 82 & 15 & 97 \\
Total & 468 & 149 & 617 \\
\hline
\end{tabular}

$\chi^{2}=4.74, P=0.02$

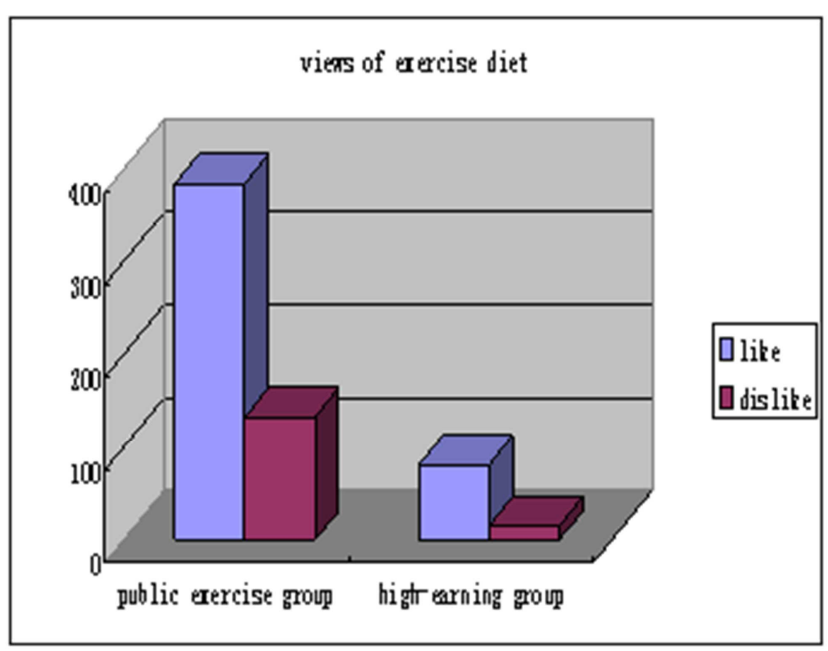

Figure 1. Histogram of the views in exercise diet.

Moreover, the percentage of objects who also think highly important on the taste is $65 \%$ (figure 2). Among 615 objects, there are 454 individuals wish to enjoy those food purchased from the green farm. (figure 3 ).



Figure 2. Pie chart of the result of the question what do you think about the food.

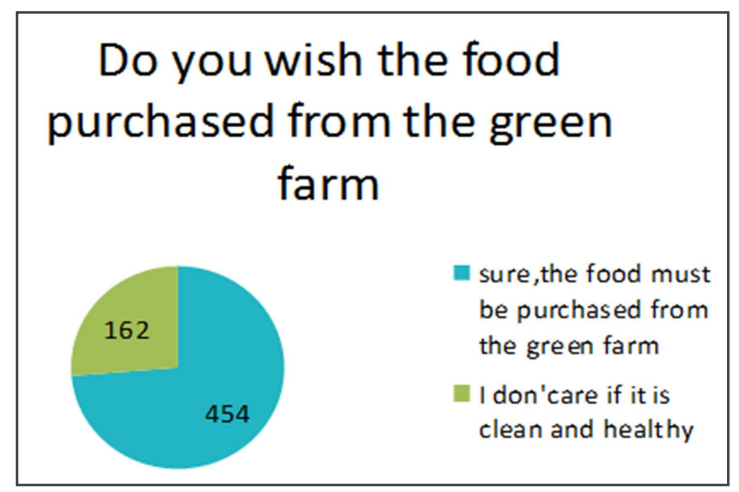

Figure 3. The result of the question whether wish the food purchased from the green farm.

By the way, when asking about the details of the third party, they consider a lot. About the location, fifty-seven point two percentage of objects hope that the company can be set near the living place, for example, near the communities or universities, while forty-one point eight percentage of them hope that it can be set near the fitness centre, office building and city centre. (figure 4)

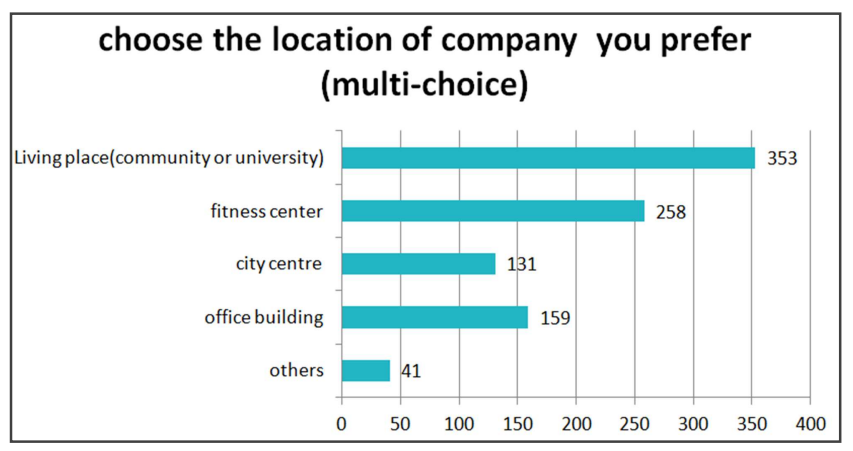

Figure 4. The choices of the location.

About the question of how to receive services, the way making recipes and ordering meals through app, then deliver the take-out rank first, there are 383 choices $(62 \%)$ in this way. Followed by the way that following the wechat public platform and order meals in the platform, then deliver the take-out, there are 383 choices $(59.4 \%$ ) in that way. (figure 5) 


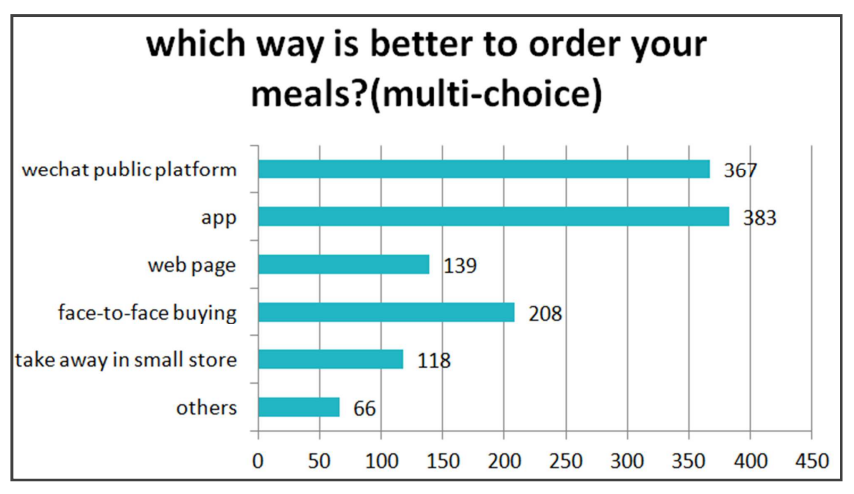

Figure 5. The choices of the way receiving services.

The last question on the questionnaire is what the place it can be. Three hundred ninety-six objects $(64.2 \%)$ will choose healthy dietary consult. While the main function of company that providing professional catering center has 355 supporters (57.5\%) (figure 6)



Figure 6. The choices of what the place company can be.

\section{Discussion}

In recent years, lots of interventional nutritional studies have been conducted, and many meta-analyses and comprehensive reviews have assessed the effects of diet to the health [2-7]. Some investigators have suggested that trained person may have a lower requirement for protein due to increased efficiency of use of protein. Accordingly, "several studies have shown that strength training, consistent with the anabolic stimulus for protein synthesis it provides, actually increases the efficiency of use of protein, which reduces dietary protein requirements" [8]. It is postulated that approximately $15-25 \%$ of the population respond to dietary cholesterol in a significant manner (i.e., sensitive or hyper-responders), while the majority respond minimally (i.e., non-sensitive or hypo-responders) [9]. Lifestyle modifications remain the cornerstone of weight management; Treatment of obesity is a difficult and complex process and limited effective obesity management systems are in place in national healthcare services around the world.

Obesity is a chronic medical condition and has continued to accelerate at an unprecedented rate in the Worldwide. It is one of the main public health problems which underlie many chronic illnesses and socioeconomic difficulties. [10] As well known, interventions to reduce calorie intake is help to keep fit.

It should be noted that although most people know that a healthy diet is meaningful and important to health, they are unable to keep a healthy diet and eat those green food because they lack of professional guidance and be limited by their work time.

With people's attention to health, sports and food rising, the demands for healthy food have a continues increase. But in this field, the market place is still blank, which related to the few number of healthy food producers and their small scale, so it has a huge marketing potential making personal ordering healthy food. And if such company will be set, it has to face lots of challenge, so analyzing the marketing conditions has significant meaning.

In this study, we assume that a third party provides balanced nutrition and healthy exercise diet to keep us energized, meanwhile it do not cause calorie overload and weight gain. It is important to gain a clear idea of who will be interesting in it and who will rely on this way to keep fit. By collecting questionnaires and analyzing the data, we got some feedbacks questionnaires shows the propotion of those who will consume exercise meals is more than $76 \%$. They will rely on third party to prepare their exercise meals especially when their self condition do not allow them to meet demands of exercise meals . Moreover, the percentage of objects who also think highly important on the taste is $65 \%$ which shows that more than half of customers require for a good taste and it means if a company should be set up, preparing not only healthy but also delicious diet is the most important task. Among 617 objects, there are $74 \%$ individuals wish to enjoy those food purchased from the green farm, which means that if a company would like to be trusted by customers, food resource should be considered reasonably.

The research results shows that $57.2 \%$ of people hope the company can be set in the communities and universities, $41.8 \%$ of people hope that it can be set near the fitness center, it can be concluded that people prefer a location which can be convenient. While in the question of choosing the kind of services, what rank first is making recipes and ordering meals through app, followed by the way that following the we chat public platform and ordering meals in the platform. Take out delivery develop in electronic platform is the needs of future development. In feedback, $64.2 \%$ of individuals believe it needs to be healthy dietary consult, while $57.5 \%$ of them think it has to be a professional catering center, we can see this potential market demand by the feedbacks.

The strengths of company contain that the company's business (custom healthy meals) can be quantified, which means the scale of the company is easy to expand with a low cost. And the raw materials are purchased from the green farm, which represent more healthy and more competitive products.

While the weaknesses are obvious, a mature distribution system should be set up and a ordering system also should be run in time because the products should be delivered to customer, and the company is operated in $\mathrm{O} 2 \mathrm{O}$ mode. Which equate a high cost at the beginning of establishing the company. 
There are lots of opportunities for it, one is that it is a emerging industry so the threat of competition is small, with the first mover advantage, the company is easy to expand and occupy the marketplace. The other opportunity rely on the increasing concept of healthy diet, as lots of people are unable to reach their healthy demands, it has a large marketing place in this field.

Besides, with a low industry entry threshold, there must be more potential competitors. And there are less relevant enterprises can be referenced because it is a emerging industry.

Previewing the future of this company from the views of marketing, there are strengths and weaknesses, opportunities and threats it will be up against. Learning how to deal with these marketing factors can help us better understand the marketplace and public opinion so it is also a important work to list them.

\section{Conclusion}

Public fitness group and high-consume group think highly important of healthy exercise diet and the high-consume group have a higher demand of private customized health fitness catering service. With there is a market gap in this field, a third party which provide healthy diet should be established to reach public healthy demands. And there are several marketing condition including customer expectations should be considered when establishing the company.

\section{Acknowledgements}

This study was supported by the National Training Program of Innovation and Entrepreneurship for Undergraduates (No. 201510560029)

\section{References}

[1] E Stice, CN Marti, S Durant .Risk factors for onset of eating disorders: evidence of multiple risk pathways from an 8-year prospective study. Behaviour research and therapy. Behav Res Ther. 2011; 49(10): 622-7.
[2] B. Enkhmaa, P. Surampudi, E. Anuurad, L. Berglund. Life style Changes: Effect of Diet, Exercise, Functional Food, and Obesity Treatment, on Lipids and Lipoproteins. In: De Groot LJ, Beck-Peccoz P, Chrousos G, Dungan K, Grossman A, Hershman JM, Koch C, McLachlan R, New M, Rebar R, Singer F, Vinik A, Weickert MO, editors. South Dartmouth (MA): MDText.com, Inc.; 2000-.2015 Jun 8.

[3] R. Arena R, C.J. Lavie CJ, M.F. Hivert, M.A. Williams, P.D. Briggs, M. Guazzi. Who will deliver comprehensive healthy lifestyle interventions to combat non-communicable disease? Introducing the healthy lifestyle practitioner discipline. Expert Rev Cardiovasc Ther. 2015 Nov 2: 1-8.

[4] M. D. Rodríguez Huerta, M. M. Trujillo-Martín, Í. Rúa-Figueroa, L. Cuellar-Pompa, R. Quirós-López, P. Serrano-Aguilar; Spanish SLE CPG Development Group. Healthy lifestyle habits for patients with systemic lupus erythematosus: A systemic review. Semin Arthritis Rheum. 2015 Oct 1. pii: S0049-0172 (15) 00232-2. doi: 10.1016/j.semarthrit. 2015.09.003.

[5] J. Antonio, A. Ellerbroek, T. Silver, S. Orris, M. Scheiner, A. Gonzalez, C.A. Peacock. A high protein diet $(3.4 \mathrm{~g} / \mathrm{kg} / \mathrm{d})$ combined with a heavy resistance training program improves body composition in healthy trained men and women--a follow-up investigation. J Int Soc Sports Nutr. 2015 Oct 20; 12: 39 .

[6] SM Howe, TM Hand, MM Manore. Exercise-trained men and women: role of exercise and diet on appetite and energy intake. Nutrients. 2014; 6(11): 4935-60.

[7] B Woynarowska, A Małkowska-Szkutnik, J Mazur, A Kowalewska, K Komosińska.School meals and policy on promoting healthy eating in schools in Poland. Med Wieku Rozwoj. 2011; 15(3): 232-9.

[8] SM Phillips. Protein requirements and supplementation in strength sports. Nutrition. 2004; 20: 689-95. doi: 10.1016/j.nut. 2004.04.009.

[9] L Djousse, JM Gaziano. Dietary cholesterol and coronary artery disease: a systematic review. Curr Atheroscler Rep. 2009; 11: 418-422.

[10] A Rahmani, K Sayehmiri, K Asadollahi, D Sarokhani, F Islami, M Sarokhani. Acta Med Iran. 2015 53(10):596-607. 